\title{
Evaluasi sikap siswa terhadap perpustakaan sekolah
}

\author{
Hanna Herfina ${ }^{1}$, Hanny Hafiar ${ }^{2}$ \\ ${ }^{1} \mathrm{SDN}$ Cibeureum Mandiri I \\ Jl. Mahar Martanegara No. 35, Cibeureum, Jawa Barat 40522 \\ 2Program Studi Hubungan Masyarakat Universitas Padjadjaran \\ Jl. Raya Bandung-Sumedang Km. 21, Jatinangor, Sumedang, Jawa Barat 45363 \\ E-mail: ${ }^{1}$ hn.herfina@gmail.com, 2hannyhafiar@gmail.com
}

Received: June 2017; Accepted: March 2018; Published: May 2018

\begin{abstract}
The school library is not yet a favorite place for elementary school students. Many factors have contributed to this, among other the types of books available, unreliable library time, non-permanent librarians, even the scorn of friends who think of reading in the library as behavior that pretending to diligent. Many factors have contributed to this, such as the types of books available, unreliable library time, non-permanent librarians, even the scorn of friends who think of reading in the library as pretending to be diligent and smart, which cause students to be reluctant to regularly visit the library. Hence, classroom teachers need to reaffirm the library functions and persuade students to visit and utilize facilities in the library. This article presents the evaluation results of students attitude after receiving information about the library described by the classroom teacher. The method used in this study was descriptive study, with fourth-grade students of an elementary primary school as the object, data collection techniques used questionnaires, and data analysis used a single tabulation based on quantitative data. The results showed that students had a better attitude toward school libraries, from the cognitive aspects were such as knowledge, trust, and assessment, and the affective as well as conative aspects. Therefore, it is expected that schools through the classroom teacher can intensively spread information about the function of school libraries, and improve library facilities and services to the students, so they are accustomed to using the library as a first step in forming the love-literacy generation.
\end{abstract}

Keywords: Library; School; Evaluation; Attitude; Student

\begin{abstract}
Abstrak
Perpustakaan sekolah belum menjadi tempat favorit bagi siswa siswi di bangku sekolah dasar. Banyak faktor yang menyebabkan hal tersebut, antara lain jenis buku yang tersedia, waktu buka perpustakaan yang tidak pasti, petugas perpustakaan yang tidak tetap, bahkan cemoohan teman yang menganggap membaca di perpustakaan sebagai perilaku yang sok rajin. Hal tersebut membuat siswa enggan untuk menjadi pengunjung rutin perpustakan. Oleh karena itu, guru kelas perlu menegaskan kembali fungsi perpustakaan dan mempersuasi siswa untuk berkunjung dan memanfaatkan fasilitas di perpustakaan. Artikel ini berisi pemaparan mengenai hasil evaluasi terhadap sikap siswa setelah menerima informasi seputar perpustakaan yang dijelaskan oleh guru kelas. Metode yang digunakan dalam riset ini adalah studi deskriptif, dengan objek siswa siswi kelas empat di sebuah sekolah dasar, dengan teknik pengumpulan data menggunakan angket, serta analisis data menggunakan tabulasi tunggal berdasarkan data kuantitatif. Hasil yang diperoleh menunjukkan bahwa siswa menjadi memiliki sikap yang lebih baik terhadap perpustakaan sekolah, baik dari: aspek kognitif meliputi: pengetahuan, kepercayaan dan penilaian; aspek afektif; maupun konatif. Oleh karena itu diharapkan sekolah melalui guru kelas dapat secara intensif menyebarkan informasi mengenai fungsi perpustakaan sekolah, serta meningkatkan fasilitas dan pelayanan perpustakaan kepada siswa dan siswinya, agar mereka terbiasa menggunakan perpustakaan sebagai langkah awal dalam membentuk generasi cinta literasi.
\end{abstract}

Kata Kunci: Perpustakaan; Sekolah; Evaluasi; Sikap; Siswa

doi: https://doi.org/10.24198/jkip.v5i2.12359

(C) 2017 Jurnal Kajian Informasi \& Perpustakaan. This is an open access article under the CC BY-SA license

Website: http://jurnal.unpad.ac.id/jkip 


\section{PENDAHULUAN}

Membaca merupakan salah satu kegiatan yang membutuhkan keahlian. Banyak orang bisa membaca, mengeja huruf per huruf, namun tak semua orang mampu membaca sekaligus memahami dan menyadari makna penting dari informasi yang dibacanya. Kemampuan membaca harus dilatih sejak dini, minimal dari pembiasaan membuka buku, mengeja kata-kata, memahami kalimat, hingga mencerna maksud dari tulisan seorang penulis.

Indonesia, bukanlah sebuah negara yang masyarakatnya menempatkan membaca informasi sebagai kebutuhan. Masyarakat Indonesia cenderung lebih menyukai mendengar informasi dari pada membaca informasi. Hal ini merujuk pada pernyataan Direktur Jenderal Sumber Daya Ilmu Pengetahuan, Teknologi, dan Pendidikan Tinggi Kemristekdikti Ali Ghufron Mukti yang dikutip melalui (Maharani, 2015) bahwa: "Selama ini minat baca dan tulis masyarakat Indonesia masih kurang. Kebiasaan masyarakat Indonesia lebih pada kebiasaan mendengar dan bercakap-cakap". Pernyataan ini didukung pula oleh Gewati (2016) yang menuliskan: Kondisi minat baca bangsa Indonesia memang cukup memprihatinkan. Berdasarkan studi Most Littered Nation In the World yang dilakukan oleh Central Connecticut State University pada Maret 2016 lalu, Indonesia dinyatakan menduduki peringkat ke-60 dari 61 negara soal minat membaca.

Oleh karena itu, sejak beberapa tahun yang lalu, pemerintah sudah menggalakkan gerakan membaca, terutama kepada anak usia dini. Walau demikian, gerakan ini juga menuai kontroversi karena bersinggungan dengan keberatan orangtua yang menyebut adanya kesan seolah memaksakan anak usia prasekolah, yang semestinya masih bermain, sudah diharuskan belajar membaca. Bahkan hal ini juga berimplikasi pada persyaratan yang ditetapkan di beberapa sekolah dasar yang mengharuskan siswa yang telah mampu membaca lebih diprioritaskan untuk diterima di sekolah tersebut. Hal tersebut tergambar dalam tulisan yang menggambarkan bahwa:

"Sebagai orangtua, Anda patut waswas jika ada Sekolah Dasar (SD) yang menjadikan kemampuan calistung sebagai syarat wajib untuk masuk ke sekolahnya. Itu berarti, sekolah tersebut kurang memahami tahapan perkembangan anak mulai dari usia 06 tahun. Dijelaskan praktisi pendidikan Najelaa Shihab, calistung memang merupakan pelajaran yang harus diajarkan di TK bahkan sebelum ia masuk lembaga pendidikan. Namun pelajaran itu tidak selalu dalam bentuk hitung-hitungan matematika atau membaca buku. Ia pun setuju dengan anggapan sejumlah orang untuk tidak memasukkan anak ke sekolah dasar yang mewajibkan bisa calistung" (Hestianingsih, 2012).

Pada saat gerakan memperkenalkan membaca kepada anak usia dini, banyak pihak yang menyetujui bahkan ajakan gerakan ini membuat sebagian sekolah mensyaratkan anak yang mendaftar ke sekolah dasar, diprioritaskan yang sudah bisa membaca bahkan menulis. Dengan harapan jika masih kecil sudah bisa membaca, maka di kemudian hari anak tersebut akan menjadikan membaca sebagai kebiasaan bahkan kebutuhan.

Selain pihak yang pro dengan gerakan tersebut, ada juga sebagian 
pihak yang kontra. Pendapat yang mengungkap-kan nada keberatan untuk memper-kenalkan membaca kepada anak usia dini juga dikemukakan berbagai kalangan, termasuk dari orang tua anak, bahkan pengamat pendidikan bagi anak-anak, sebagian berpendapat bahwa usia anak di bawah lima tahun sebaiknya tidak dipaksakan belajar secara akademik namun membuka kesempatan mem-pelajari sesuatu secara otodidak dan alamiah, seperti yang dikemukakan Zulhaqi (2013) bahwa banyaknya anak usia taman kanak-kanak (TK) sudah diajarkan membaca, menulis dan berhitung (calistung). Jika hal ini dipaksakan, tidak akan efektif dan pasti akan ada efeknya mengingat anak pada usia prasekolah akan optimal jika diberi stimulasi atau rangsangan motorik dan bahasa sesuai fase tumbuhkembang anak.

Walau gerakan memperkenalkan membaca pada usia dini tetap dijalankan dengan segala pro dan kontranya, kebiasaan membaca siswa SD di Indonesia ternyata masih minim. Minimnya kebiasaan membaca anak Indonesia, disinyalir disebabkan oleh berbagai faktor, antara lain pro dan kontra masyarakat akan gerakan membaca bagi anak usia dini. Selain itu juga masih kurangnya fasilitas yang mendukung anak untuk suka membaca. Pola baca keluarga juga mempengaruhi kebiasaan membaca anak. Keluarga yang tidak memiliki kebiasaan membaca cenderung tidak memiliki koleksi bacaan yang memadai, bahkan keluarga yang memiliki kebiasaan membaca pun, acap kali belum memiliki koleksi bacaan yang sesuai dengan kondisi anak baik isi maupun format.
Hal ini mengundang reaksi dari berbagai pihak untuk menyediakan taman bacaan bagi masyarakat umum dalam berbagai bentuk. Mulai dari perpustakaan keliling, perpustakaan yang tersedia di berbagai tingkat kelurahan, hingga perpustakaan sekolah yang berada di pelosok daerah. Pemerintah melalui Kemendiknas telah berupaya untuk menggenjot jumlah pertumbuhan perpustakaan di sekolahsekolah, termasuk di sekolah dasar. menurut Keputusan Presiden RI nomor 11, disebutkan bahwa:

"Perpustakaan merupakan salah satu sarana pelestarian bahan pustaka sebagai hasil budaya dan mempunyai fungsi sebagai sumber informasi ilmu pengetahuan, teknologi dan kebudayaan dalam rangka mencerdaskan kehidupan bangsa dan menunjang pelaksanaan pembangunan nasional. Adapun pengertian perpustakaan sekolah adalah perpustakaan yang berada dalam suatu sekolah yang kedudukan dan tanggung jawabnya kepada kepala sekolah; yang melayani civitas akademika sekolah yang bersangkutan" (Surachman, 2013).

Upaya-upaya tersebut diharapkan dapat mendongkrak jumlah materi bacaan yang dikemas dalam berbagai format semenarik mungkin agar memancing minat baca masyarakat terutama anakanak, sehingga membaca dapat dijadikan kebiasaan dalam kehidupan sehari-hari. Hal ini sesuai dengan pendapat bahwa kehadiran perpustakaan dapat diarahkan kepada banyak tujuan di antaranya Memasyarakatkan atau membudayakan minat baca masyarakat, yang sejauh ini dinilai masih sangat rendah (Darmayanti, 2016). Namun demikian, pertumbuhan jumlah perpustakaan, tidak akan berhasil secara optimal jika tidak dibarengi dengan 
peningkatan kemampuan literasi informasi.

Literasi informasi diartikan sebagai bentuk kajian ilmu informasi dan perpustakaan yang fokus kepada kemampuan individu atau kelompok untuk mencari, memperoleh, mengevaluasi dan menggunakan informasi tersebut untuk kebutuhan atau pemecahan masalah baik dalam skala kecil (pribadi) atau skala besar (masyarakat) (Senova, 2014).

Rendahnya kemampuan literasi, dapat disebabkan pula oleh faktor lingkungan yang tidak mendukung. Hal ini selaras dengan pernyataan bahwa: tumbuhnya literasi anak ini perlu diikuti dengan upaya nyata yang dilakukan oleh manusia dewasa disekitarnya (Antasari, 2016). Pernyataan tersebut menunjukkan pentingnya peranan orang dewasa dalam membentuk literasi anak. Orang dewasa yang dimaksud dapat berupa significant others bagi seorang anak, diantaranya orangtua, orang yang lebih tua dan dewasa di dalam keluarga, maupun di sekolah.

Oleh karena itu diperlukan penjelasan guru kelas mengenai fungsi perpustakaan sekolah kepada siswa-siswi didiknya, agar perpustakaan sekolah dapat berfungsi secara optimal sesuai dengan peruntukkannya. Penjelasan guru kelas mengenai perpustakaan sekolah diharapkan akan dapat menjadi pengetahuan yang bermanfaat bagi siswa. Pengetahuan merupakan indikator dari aspek kognisi dalam sikap yang akan menghasilkan sikap tertentu (Komariah, Perbawasari, Nugraha, \& Budiana, 2013). Sedangkan sikap merupakan reaksi atau respon yang masih tertutup dari seseorang terhadap suatu stimulus atau objek. Allport (1954) menjelaskan bahwa: "Sikap mempunyai tiga komponen pokok: a) Kepercayaan (keyakinan), ide, konsep terhadap suatu objek. b) Kehidupan emosional atau evaluasi terhadap suatu objek. c) Kecenderungan untuk bertindak (tend to behave). Sikap merupakan kecenderungan atau kesediaan untuk bertindak" (Notoadmodjo, 2011)

"Seperti halnya dengan pengetahuan, sikap ini juga terdiri dari berbagai tingkatan, yaitu: a) Menerima (receiving) Menerima diartikan bahwa orang (subyek) mau dan memperhatikan stimulus yang diberikan (obyek). b) Merespon (responding) Memberikan jawaban apabila ditanya, mengerjakan dan menyelesaikan tugas yang diberikan adalah suatu indikasi dari sikap karena dengan suatu usaha untuk menjawab suatu pertanyaan atau mengerjakan tugas yang diberikan terlepas pekerjaan itu benar atau salah berarti bahwa orang menerima ide tersebut. c) Menghargai (valuing) Mengajak orang lain untuk mengerjakan atau mendiskusikan suatu masalah, merupakan suatu indikasi sikap tingkat tiga. d) Bertanggung jawab (responsible) Bertanggung jawab atas segala sesuatu yang telah dipilihnya dengan segala resiko merupakan sikap yang paling tinggi" (Setyaningsih, 2012).

Membaca merupakan salah satu pintu masuk untuk mencapai prestasi akademik, oleh karena itu membaca harus dibudayakan. Proses pembudayaan di sekolah adalah untuk pencapaian akademik siswa, untuk membudayakan sikap, pengetahuan, keterampilan dan tradisi yang ada dalam suatu komunitas budaya, serta untuk mengembangkan budaya dalam suatu komunitas melalui 
pencapaian akademik siswa (Fauji \& Ernestivita, 2015).

Selain pembudayaan di sekolah, pembudayaan membaca dapat dilakukan di rumah, karena kebiasaan membaca yang dilakukan anak-anak, cenderung dipengaruhi budaya membaca yang diinterlasisasi anak dari keluarganya (Hafiar \& Sani, 2015). Di samping membudayakan membaca, diperlukan pula ketersediaan fasilitas pepustakaan sekolah yang berorientasi pada kebutuhan siswa agar dapat menarik minat siswa untuk mengunjungi, membaca, dan meminjam buku-buku yang disediakan oleh perpustakaan sekolah. Hal ini merujuk pada kutipan: kualitas layanan perpustakaan mengacu kepada kebutuhan pemustaka. Oleh sebab itu, layanan yang baik adalah layanan yang dapat memenuhi kebutuhan dan harapan pemustaka (Rodin, 2015).

Terdapat pendapat yang menyatakan bahwa: dalam kelompok teman sebaya, remaja mendapatkan perangkat nilai dan sistem etis sebagai pegangan sikap dan perilaku remaja untuk mengembangkan ideologinya (Aryanti, 2014). Pendapat serupa juga dinyatakan: Proses-proses perubahan secara psikologis (perubahan kognitif, emosi, kepribadian dan moral) dan secara sosiologis berlangsung pada masa remaja yang dipengaruhi oleh masyarakat, teman sebaya dan media massa. Remaja dalam Setianti \& Hafiar (2009) artinya, teman sepergaulan memiliki peran penting dalam menumbuhkan motivasi dan kebiasaan membaca. Motivasi ini juga dapat berkaitan dengan pemilihan individu terhadap hal-hal yang diminati di masa depan (Setyaningsih, 2012). Dengan demikian penelitian ini bertujuan untuk mengetahui tentang sikap siswa terhadap perpustakaan setelah menyimak penjelasan guru kelas mengenai fungsi perpustakaan sekolah.

\section{METODE PENELITIAN}

Metode yang digunakan dalam penelitian ini adalah metode deskriptif yaitu dengan menjabarkan hasil penelitian, untuk menganalisis data-data yang diperoleh dari hasil penelitian dengan mentabulasi data yang didapat melalui keterangan responden, kemudian dicari frekuensi dan persentasenya. Setelah itu disusun dalam bentuk tabel tunggal dengan menggunakan skala likert yang terdiri dari tiga kategori atau kelas. (Simanjorang, 2013). Adapun teknik pengumpulan data dilakukan dengan cara menyebarkan instrumen sederhana untuk mengetahui sikap siswa. Siswa yang menjadi sampel sebanyak 15 orang di sebuah sekolah dasar negeri. Adapun teknik analisis data dilakukan dengan deskriptif kuantitatif menggunakan distribusi frekuensi.

\section{HASIL DAN PEMBAHASAN}

Pada bagian instrumen penelitian, peneliti berupaya menggali kognisi siswa yang menjadi responden. Adapun yang dipertanyakan kepada siswa adalah yang berkaitan dengan pengetahuan, penilaian serta kebermanfaatan perpustakaan yang dipercayai siswa dimiliki oleh perpustakaan sekolahnya. Sebelumnya, para siswa diberi penjelasan terlebih dahulu beberapa informasi mengenai perpustakaan oleh guru kelas. Informasi yang disampaikan guru antara lain adalah buku-buku yang dianggap memiliki isi yang dapat menarik minat membaca siswa.

Setelah itu, siswa diajak untuk mengunjungi perpustakaan dan diberitahu 
tentang prosedur penggunaan fasilitas di perpustakaan. Informasi lain yang diberikan adalah mengenai tata aturan sikap yang diperbolehkan dan tidak diperbolehkan selama berkaitan dengan perpustakaan. Misalnya cara menjaga sikap di dalam perpustakaan, serta aturan peminjaman. Selanjutnya, siswa pun dipersilahkan untuk menggunakan perpustakaan secara mandiri namun tetap dengan pendampingan. Berdasarkan data yang berhasil dikumpulkan melalui instrumen angket, diperoleh sejumlah bahan yang dapat dianalisis, berkaitan dengan hasil evaluasi sikap siswa terhadap perpustakaan sekolah, setelah memperoleh penjelasan dari guru kelas mengenai perpustakaan. Antara lain:

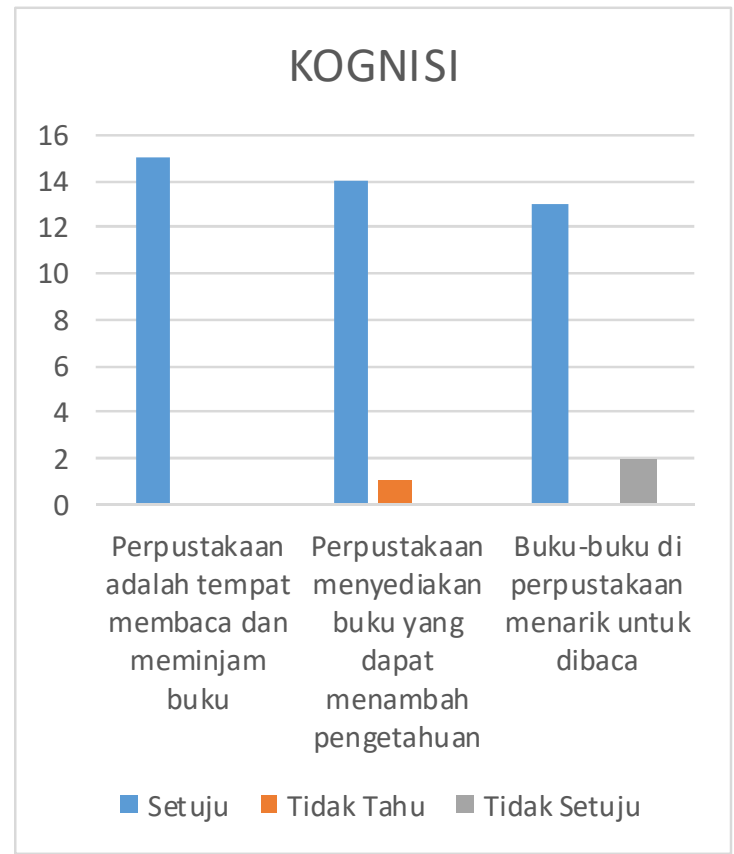

Gambar 1. Kognisi siswa mengenai perpustakaan Sumber: hasil penelitian, 2017

Terdapat sejumlah gambaran pengetahuan mengenai perpustakaan sekolah, berkaitan dengan fasilitas yang disediakan perpustakaan. Jika sebelumnya, terdapat siswa yang merasa ragu untuk melakukan peminjaman, dan hanya berkunjung ke perpustakaan untuk membaca di tempat. Kini, seluruh siswa mengetahui bahwa buku-buku di perpustakaan boleh dipinjam, alias boleh di bawa ke rumah masing-masing untuk dikembalikan sesuai waktu yang diperjanjikan.

Hal ini juga didukung oleh data hasil observasi yang memperlihatkan adanya siswa yang biasa meminjam buku yang dipinjam temannya di perpustakaan, untuk dibacanya di sekolah, sebelum buku itu dibawa temannya pulang dan dibaca di rumah. Kini, ia sudah mencoba meminjam secara mandiri dengan mendaftarkan diri sebagai anggota perpustakaan hingga ia bisa meminjam langsung dari perpustakaan dan membaca buku tersebut secara lebih leluasa di rumah. Keberanian ini muncul setelah mendapat tambahan pengetahuan mengenai perpustakaan yang dijelaskan oleh guru kelas.

Mengacu pada gambaran penge-tahuan berdasarkan penjelasan yang diperoleh dari guru kelas mengenai aturan yang berlaku di perpustakaan sekolah, maka dapat dikatakan bahwa kini, seluruh siswa telah memperoleh informasi mengenai fasilitas peminjaman buku di perpustakaan sekolah.

Informasi diartikan sebagai suatu rekaman fenomena yang diamati, atau bisa juga berupa putusan-putusan yang dibuat seseorang. Informasi bisa berupa kumpulan-kumpulan data yang dirangkum secara sistematis dan memiliki keabsahan atas isi yang terkandung didalamnya (Senova, 2014).

Selanjutnya, berkaitan dengan indikator kepercayaan yang merupakan bagian dari sikap diketahui bahwa hampir seluruh siswa mempercayai bahwa bukubuku yang disediakan di perpustakaan dapat menambah pengetahuan. Namun, masih terdapat sebagian kecil siswa yang menyatakan tidak tahu. Hal ini disebabkan 
siswa tersebut belum pernah sekali pun mengunjungi perpustakaan sekolah. Beberapa alasan dikemukakan, bahwa untuk meminjam dan membaca buku di perpustakaan itu kurang menyenangkan dibandingkan dengan bermain bersama teman-temannya. Selain itu, membaca buku di sela waktu istirahat yang di jadwalkan di sekolah dianggap menambah kepusingan, karena selama mengikuti pelajaran sebagian anak-anak justru mengharapkan lonceng penanda waktu istirahat ataupun waktu pulang segera berbunyi, agar mereka bisa segera bersantai dan tidak merasa dituntut untuk memikirkan pelajaran apalagi membaca buku di perpustakaan.

Hal tersebut menunjukkan bahwa siswa yang menyatakan tidak tahu, merupakan siswa yang belum memahami pentingnya literasi informasi, sehingga belum memiliki kemampuan untuk memanfaatkan sumber informasi. Hal ini sejalan dengan:

Literasi informasi menurut American Library Association (ALA) is a set of abilities requiring individuals to recognize when information is needed and have the ability to locate, evaluate, and use effective needed information (American Library Association, 1989). Maksudnya, kemampuan individu untuk mengidentifikasi informasi yang dibutuhkan, kemampuan untuk mengakses dan menemukan informasi, kemampuan mengevaluasi informasi dan kemampuan menggunakan informasi tersebut secara efektif (Khadijah, Rejeki, Sukaesih \& Anwar, 2016).

Oleh karena itu penting lah kiranya setiap guru menjelaskan mengenai pentingnya membaca dan fungsi perpustakaan, guna menciptakan generasi muda yang cinta membaca dan akrab dengan sumber informasi, sebagai upaya mencerdaskan kehidupan bangsa melalui buku. Bagi siswa yang memiliki pola belajar hanya bergantung pada penjelasan guru di kelas, pada umumnya akan hanya membaca buku pelajaran yang diwajibkan guru kelas. Oleh karena itu, perlu kiranya guru mulai mengarahkan siswa untuk belajar mencari referensi lain di perpustakan, sehingga siswa menjadi terpancing untuk mengunjungi perpustakaan, agar perpustakaan pun dapat difungsikan secara optimal. Hal ini sesuai dengan pendapat bahwa: "Dalam pembelajaran di kelas belum ada kegiatan yang menuntut peserta didik menggunakan buku referensi yang ada di perpustakaan sehingga frekuensi peserta didik membaca buku masih kurang" (Zulnuraini, 2012). Adapun salah satu fungsi perpustakaan dinyatakan sebagai berikut:

Salah satu fungsi perpustakaan adalah sebagai sumber informasi yang berperan penting dalam menciptakan masyarakat yang literasi untuk mencerdaskan kehidupan bangsa dan menunjang pelaksanaan pembangunan nasional dan dimanfaatkan oleh masyarakat. Perpustakaan hendaknya memberikan stimulus kepada user agar masyarakat mau datang ke perpustakaan dengan berbagai cara dan pendekatan, untuk menciptakan masyarakat menjadi masyarakat yang melek informasi atau yang biasa disebut masyarakat literasi informasi (Darmayanti, 2016)

Untuk memancing minat siswa yang belum memiliki kegemaran membaca buku, perlu dilakukan beberapa strategi, antara lain dengan menawarkan buku bacaan yang ringan, seperti buku bacaan yang disertai gambar dan tak melulu tulisan. Oleh karena itu pada saat 
pengadaan koleksi buku, perlu dipertimbangkan sebuah strategi yang dapat menarik perhatian siswa yang sebelumnya belum memiliki minat membaca buku. Kegiatan pengadaan tidak pernah terlepas dari koleksi fiksi, mengingat salah satu fungsi perpustakaan yang juga sebagai pemenuh kebutuhan rekreasi (Muliasari \& Suhardini, 2016).

Berdasarkan penjelasan tersebut, maka perlu dipertimbangkan dalam proses peng-ambilan keputusan mengenai penyediaan jenis buku bacaan yang sesuai dengan target sasara. Mengingat sejumlah siswa masih merasa bahwa buku yang disediakan di perpustakaan sekolah dinilai sebagai buku yang dianggap menarik. Oleh karena itu, ada baiknya perpustakaan sekolah melengkapi koleksinya dengan komik edukatif.

Bonnef (1998) mengungkapkan bahwa komik juga memiliki peranan yang positif untuk mengembangkan kebiasaan membaca, dan komik merupakan salah satu alat komunikasi massa yang memberi pendidikan baik untuk anak-anak maupun orang dewasa, komik juga dapat membawa emosi pembaca saat membaca cerita yang ada di dalamnya (Alfiyani, Mardiati, \& Khutobah, 2015).

Hal ini sesuai dengan pendapat yang menyatakan bahwa: indikator yang baik sepatutnya disusun berdasarkan kebutuh-an identifikasi persepsi pemustaka, sikap pemustaka, dan konsumsi (informasi) pemustaka. Artinya, indikator dibentuk berdasarkan kebutuhan pemustaka. (Sugara, Rusmono, \& Agustina, 2016). Oleh sebab itu, perlu kiranya dilakukan kegiatan bench marking atau pun riset dengan skala kecil untuk mengetahui selera siswa dalam menambah koleksi perpustakaan, agar fasilitas perpustakaan dapat berjalan dan berkembang sesuai dengan kebutuhan target sasaran. Saran tersebut merujuk pada pernyataan:

Menurut Stueart dan Moran (2002), perpustakaan adalah sebuah sistem yang terbuka. Sistem yang terbuka mengakui adanya hubungan yang dinamis antara sistem dengan lingkungannya. Organisasi menggunakan sumber daya manusia, dan sumber daya lainnya dari lingkungannya. Selain itu penyerapan luaran (output) organisasi juga tergantung kepada lingkungannya yaitu para pengguna atau pencari informasi. Sebuah sistem perpustakaan memiliki interaksi yang dinamis dengan lingkungannya (Diniarti, Rohanda, \& Sinaga, 2013).

Berikutnya adalah penjabaran mengenai hasil dan pembahasan yang berkaitan dengan afeksi siswa terhadap perpustakaan, setelah menyimak penjelasan guru kelas mengenai perpustakaan sekolah. Sebagian siswa yang menjawab pertanyaan yang diajukan dalam angket menunjukkan kecenderungan perasaan yang positif dan negatif terhadap sesuatu hal yang berkaitan dengan perpustakaan.

Perasaan merupakan bagian dari sikap yang akan mendorong individu untuk dengan rela melakukan sesuatu. Jika seseorang memiliki perasaan positif terhadap sesuatu maka ia akan cenderung mau untuk melakukan suatu tindakan tertentu. Misalnya, jika seorang siswa menyukai gambar menggambar, maka ia akan memiliki minat untuk membuka buku yang sarat dengan gambar. Jika seorang siswa tidak menyukai science, maka ia tidak akan tertarik dengan sebuah buku yang menceritakan kisah inspiratif dari para penemu yang dinyatakan bejasa dalam ilmu pengetahuan dan peradaban manusia. Oleh karena itu afeksi siswa 
terhadap perpustakaan harus diketahui agar lebih mudah mengarahkan siswa tersebut untuk menjadi pengunjung setia perpustakaan. Adapun hasil yang ditunjukkan dari pengukuran afeksi siswa tentang sesuatu yang berkaitan dengan perpustakaan adalah sebagai berikut:

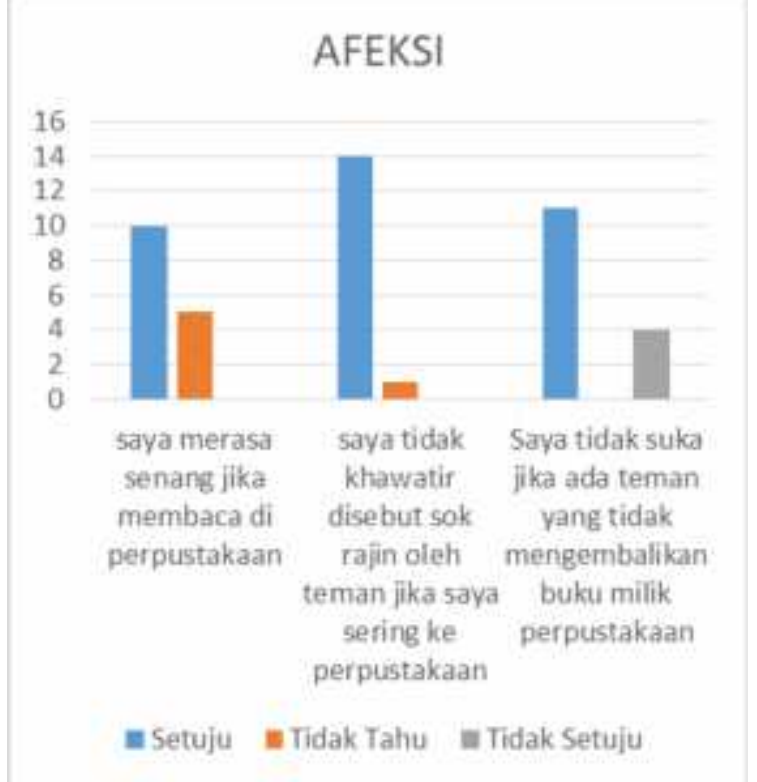

Gambar 2. Afeksi siswa mengenai perpustakaan Sumber: hasil penelitian, 2017

Sebagai Makhluk berfikir, manusia membutuhkan sumber informasi yang dapat digunakannya dalam proses pengambilan keputusan sebagai upaya memecahkan masalah. Berbagai masalah yang dihadapi manusia, pada dasarnya pernah dialami oleh manusia lain. Terdapat beberapa sumber bacaan yang mengandung pengalaman berharga tentang cara menghadapi masalah atau hambatan tertentu. Informasi yang diperoleh dari sumber bacaan seperti itu dapat menghindarkan kita dari trial and error dan meminimalisasi resiko, walaupun setiap persoalan tidak ada yang bersifat sama persis, namun pola dan kecenderungan penyelesaian dapat dipelajari dengan cara membaca, sehingga tak melulu harus bersifat empiris atau dialami langsung. Dalam kajian informasi dan perpustakaan, terdapat istilah biblioterapi.

Biblioterapi bertujuan membantu seseorang memecahkan permasalahannya melalui literatur, buku, dan sumber informasi lainnya (Biblio). Penggunaan berbagai sumber bacaan atau literatur untuk memecahkan permasalahan yang berkaitan dengan emosional, dan penyakit mental atau membantu mengubah perilaku seseorang untuk mencapai kehidupannya. Intinya biblioterapi memberikan layanan kepada seseorang dalam mencapai tujuan hidupnya yang sedikit mengalami hambatan baik emosional maupun mental (Agustina, 2014).

Contoh dari sumber bacaan yang bersifat biblioterapi adalah buku-buku yang setelah membacanya, pembaca akan merasakan adanya perasaan yang lebih baik dari sebelumnya. Misalnya, sebelum membaca, seseorang tidak mengetahui cara kerja pesawat dan mengapa pesawat bisa terbang dengan tenang di udara. Ketidaktahuannya ini akan menimbulkan ketakutan dan keresahan saat ia diharuskan naik pesawat untuk mengunjungi tempat tertentu. Setelah ia membaca informasi tentang cara kerja pesawat dan faktor yang dapat meningkatkan keamanan berkendaraan dengan menggunakan kapal terbang, maka ia akan relatif merasa tenang saat harus menaiki pesawat. Perasaan merasa tenang setelah mengetahui tentang sesuatu tersebut, merupakan bagian dari biblioterapi.

Selain perasaan tenang, munculnya perasaan senang setelah membaca bacaan yang mengandung unsur humor pun termasuk perasaan yang positif. Lebih dari separuh siswa menyatakan senang apabila memiliki keempatan untuk membaca di 
perpustakaan. Adapun alasan yang dikemukakan salah satunya adalah karena saat bersedih, jika membaca buku yang lucu, merasa sedikit terhibur. Hal ini menunjukkan bahwa buku sebagai sumber informasi dapat berfungsi sebagai alat yang dapat digunakan untuk mengubah perasaan menjadi lebih baik.

Terdapat beberapa konsekuensi dari kegemaran membaca, selain konsekuensi positif, terdapat pula konsekuensi negatif. Sebuah kisah klasik, jika di sekolah terdapat siswa yang rajin mengunjungi dan membaca di perpustakaan akan mendapat labelling si kutu buku. Labelling ini adalah penjulukkan yang bersifat negatif. Hal ini dapat menurunkan semangat siswa untuk mengunjungi dan membaca di perpustakaan, karena menghindari pelabelan atau lebih jauh lagi pem-bullyan. Oleh karena itu diperlukan peran guru untuk memantau perkembangan karakter anak didiknya. Hal ini sejalan dengan temuan riset yang menyatakan:

“Guru hendaknya senantiasa mengawasi dan memantau perkembangan karakter peserta didik baik di dalam kelas maupun di luar kelas dan keteladanan dari pendidik lebih ditingkatkan dengan menjadikan diri sendiri sebagai figur teladan yang baik bagi peserta didik dan hal itu tidak hanya dilakukan oleh Kepala Madrasah dan seluruh guru harus menjadi teladan yang baik bagi peserta didik" (Puspita, 2015).

Hal yang patut disyukuri oleh pihak sekolah dalam riset kali ini, hampir seluruh siswa menyatakan bahwa mereka tidak merasa khawatir dengan pelabelan dari teman sehubungan dengan kebiasaannya mengunjungi dan membaca buku di perpustakaan. Walau bagaimana- pun, di kalangan anak sekolah, anak yang rajin membaca justru diolok-olok dengan sebutan "Kutu Buku" seolah kebiasaan membaca sebagai hal yang aneh (Setianti, Hafiar, \& Nugraha, 2009). Hal yang sebaliknya justru diketahui bahwa, sebagian siswa justru merasa suka memperoleh pujian dari teman bahwa mereka dikategorikan sebagai anak yang rajin membaca.

Namun demikian, terdapat keluhan dan ketidaksukaan siswa berkaitan dengan kebiasaan teman yang acap kali terlambat mengembalikan buku. Padahal buku yang telat dikembalikan tersebut, merupakan buku yang diincar siswa lain untuk dibaca atau dipinjam ke rumah. Fenomena ini biasanya berlaku saat ada buku baru atau buku yang dianggap menarik dan sudah dibaca oleh seorang siswa yang merekomendasikan pada temannya.

Oleh karena itu dibutuhkan kreativitas guru untuk meminimalisasi konflik di antara siswa. Dapat dicoba sebuah teknik mendongeng untuk berkisah tentang isi buku yang dipersengketakan di antara siswa. Namun tentu saja guru harus membekali diri dengan keterampilan mendongeng.

Mendongeng/bercerita merupakan keterampilan berbahasa lisan yang bersifat produktif. Dengan demikian, mendongeng/bercerita menjadi bagian dari keterampilan berbicara. Keterampilan mendongeng sangat penting bagi penumbuh kembangan keterampilan berbicara bukan hanya sebagai keterampilan berkomunikasi, melainkan juga sebagai seni. Dikatakan demikian karena mendongeng memerlukan kedua keterampilan berbicara tersebut (Fakhrudin, 2003). 
Faktor-faktor lain yang dapat menimbulkan keengganan siswa untuk membaca di perpustakaan sekolah, antara lain dikemukakan sebagai berikut: Kendala-kendala tidak meningkatkan minat baca siswa terdiri dari: kendala keterbatasan waktu di sekolah terhadap membaca di perpustakaan, kurangnya variasi dan jumlah koleksi, jarangnya penyelenggaraan story telling, dan yang terakhir kendala dalam ketersediaan perpustakaan keliling terhadap minat baca (Aini, 2011).

Permasalahan minimnya koleksi tidak hanya terjadi di perpustakaan sekolah, tapi juga terjadi di beberapa taman bacaan yang diperuntukkan bagi masyarakat luas terutama di daerah pedesaan. Data dari Perpustakaan Nasional menunjukkan bahwa minat atau budaya membaca buku di kalangan masyarakat Indonesia, terutama di daerah terpencil atau desa-desa hingga saat ini masih rendah atau kurang menggembirakan. "Belum menggembirakan ini salah satunya bukan karena tidak minat, melainkan ketersediaan buku yang bisa merangsang mereka untuk membaca juga kurang" (Masengi, Tabaga, \& Walandouw, 2014).

Selain faktor di atas, ketentraman dan kenyamanan membaca di perpustakaan juga menjadi salah satu hal yang perlu perhatian. Hal ini senada dengan pendapat yang menyebutkan: Buku-buku yang disediakan di perpustakaan belum lengkap dan sudah mulai usang sehingga peserta didik tidak berminat untuk membaca buku, selain itu petugas perpustakaan juga kurang tegas menegur para peserta didik yang bermain di perpustakaaan. Sekolah seharusnya mampu menciptakan suasana membaca yang nyaman dan tentram sehingga mampu menarik minat baca peserta didik. Selain itu, buku-buku yang ada di perpustakaan harus selalu update (Zulnuraini, 2012).

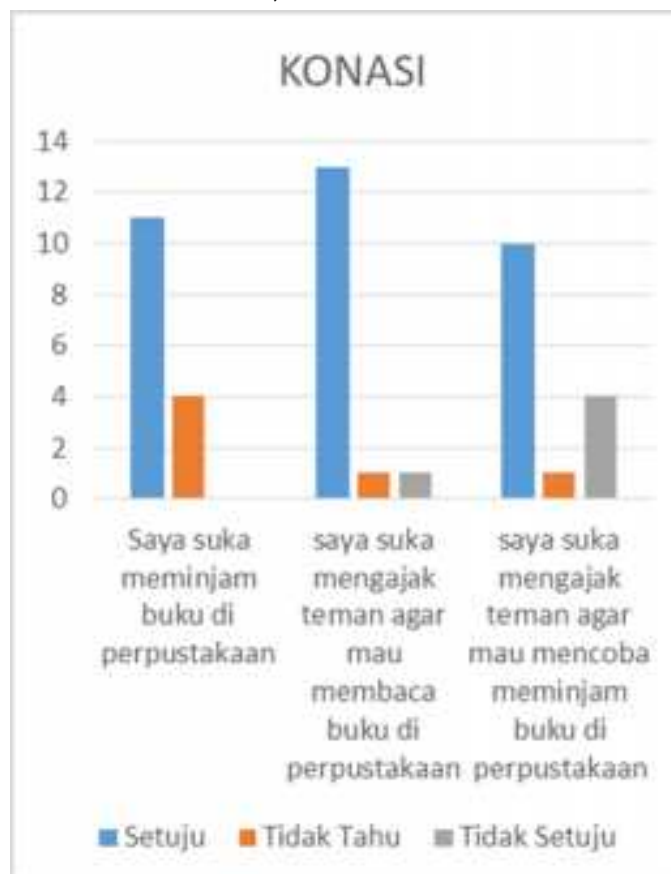

Gambar 3. Konasi siswa mengenai perpustakaan Sumber: hasil penelitian, 2017

Sebagian besar siswa menyatakan bahwa mereka suka meminjam buku di perpustakaan, minimal satu kali. Namun masih terdapat beberapa siswa yang belum pernah melakukannya. Hal ini disebabkan siswa beralasan tidak terlalu suka membaca. Pada usia dini, kebiasaan membaca dapat ditularkan oleh kebiasaan membaca orangtuanya. Hal ini merujuk pada:

"Ada beberapa saran untuk meningkatkan dukungan orangtua terhadap minat baca anak, antara lain: Hendaknya menjadikan kegemaran anak terhadap dongeng/cerita menjadi penyemangat orang tua dan guru bahwa anak-anak mempunyai modal awal untuk menjadi literat. Mulai merancang untuk mengadakan bahan bacaan baik legenda, fabel maupun IPTEK untuk anak-anak di rumah dan di sekolah. Hendaknya 
kesadaran anak yang menganggap bahwa membaca itu penting dapat memacu orang tua dan guru untuk ikut memberi contoh (teladan) untuk membiasakan membaca. Hendaknya orang tua mulai menyadari pentingnya memberikan cerita/dongeng dan menyediakan bahan bacaan di rumah. Kebiasaan orang tua menyuruh membaca dan mendampingi anak membaca hendaknya diteruskan. Kebiasaan orang tua memberikan hadiah kepada anak, hendaknya mulai dipertimbangkan untuk memberi hadiah buku bacaan" (Antasari, 2016).

Selain kebiasaan membaca yang dimiliki orangtua, pola pendidikan melalui komunikasi keluarga terhadap anak di rumah juga turut berperan dalam menumbuhkembangkan kecintaan anak untuk membaca. McLeod dalam Kline \& Tinheor, 1972 menyatakan empat (4) pola komunikasi yang ada di dalam keluarga, yaitu: (1). Democratic Family Communication Pattern (Pola Komunikasi Demokratis); baik orang tua maupun anak memiliki posisi yang setara dalam berkomunikasi (2). Protective Family Communication Pattern (Pola Komunikasi Protektif); orang tua yang cenderung terlalu melindungi anaknya, dengan pola komunikasi demikian menyebabkan anak kurang mandiri. (3). Laissez Faire Family Communication Pattern (Pola Komunikasi Laissez Faire); orang tua cenderung permisif dalam berkomunikasi dengan anaknya, sehingga seolah-olah posisi anak berada di atas orang tuanya pada saat berkomunikasi.(4). Authoritarian Family Communication Pattern (Pola Komunikasi Otoriter); orang tua yang cenderung menganggap anak sebagai komunikan yang wajib tunduk pada perintah orang tua. Pola komunikasi ideal yang dapat diterapkan di dalam keluarga adalah pola komunikasi demokratis dengan ciri posisi orang tua seolah setara dalam berkomunikasi baik pada saat menjadi komunikator ataupun komunikan (Hafiar \& Sani, 2015).

Hasil lain menunjukkan bahwa, sebagian besar siswa sudah sempat melakukan upaya mengajak teman untuk mengunjungi perpustakaan bahkan mengajak teman untuk bersama-sama meminjam buku di perpustakaan. Sesungguhnya, upaya siswa untuk mengajak temannya berkunjung ke perpustakaan merupakan proses sosial (Sugara et al., 2016). Oleh karena itu tak mengherankan jika siswa yang menyukai membaca buku akan cenderung memiliki kedekatan dengan sesama siswa yang memiliki kesukaan yang sama. Hal ini sejalan dengan pernyataan bahwa: setiap orang mempunyai pengalaman, preferensi, pendidikan tertentu dan lingkungan pergaulan atau sosial tertentu (Gemiharto, 2015).

Sedangkan bagi siswa yang enggan mengunjungi perpustakaan, diketahui salah satu alasannya adalah karena merasa "bukan anak pintar". Hal tersebut disepakati oleh sebuah hasil penelitian lain yang menyebutkan bahwa: sejumlah fasilitas membaca, seperti perpustakaan, terasa menakutkan karena terkesan hanya orang sekolahan (orang pintar) yang masuk ke dalam perpustakaan. Oleh karena itu perasaan subordinat, yang ada di dalam diri siswa harus dikikis secara perlahan dengan meningkatkan motivasi.

Dilihat dari tingkat kunjungan siswa ke perpustakaan yang jarang dilakukan. Para siswa lebih memilih di kelas, bercerita dengan teman, dibandingkan dengan membaca buku ke 
perpustakaan. Rendahnya minat baca siswa disebabkan siswa kurang memiliki perasaan, perhatian terhadap buku dan manfaat membaca, serta motivasi dari diri sendiri maupun dari orang lain (lingkungan). Faktor-faktor yang mempengaruhi minat baca siswa adalah faktor yaitu: faktor internal (perasaan, perhatian dan motivasi) (Triatma, 2016).

Membaca memang membutuhkan upaya tertentu, terlebih sengaja mengunjungi perpustakaan untuk tujuan membaca semata, dibutuhkan tekad yang kuat agar tidak terdistraksi. Hal ini harus benar-benar dipahami, sebab sebuah perbuatan baik dan bermanfaat secara alamiah akan lebih banyak godaan dan gangguannya. Namun demikian, tetap diperlukan pengkondisian lingkungan agar setiap individu, termasuk siswa sekolah dasar dapat memupuk minat bacanya.

Minat baca perlu ditanamkan dan dipupuk pada diri setiap manusia (siswa) baik oleh diri sendiri atau oleh orang lain, untuk dapat diharapkan prestasinya terus meningkat di masa yang akan datang. Guna meningkatkan minat baca ada banyak cara yang perlu dilakukan, termasuk diantaranya seperti: Pertama, berusaha untuk selalu menyediakan waktu untuk membaca secara rutin. Haruslah kita sadari bahwa orang yang dapat membaca dengan baik adalah orang yang biasa berpikir dengan baik pula. Kedua, biasakanlah untuk dapat memilih bacaan yang baik dan kita butuhkan. Masalah yang sering kita hadapi adalah kita dapat belum dapat memilih buku bacaan yang baik, juga karena terbentur oleh sempitnya waktu hingga kita tidak dapat membaca buku dalam jumlah yang banyak.oleh karena itu diperlukan keterampilan dalam memilih bahan bacaan (Tarigan, 2008).

Terdapat sejumlah rekomendasi yang diperkuat referensi untuk meningkatkan minat baca individu secara umum yang dapat bersinergi dengan fungsi perpustakaan, baik perpustakaan umum, maupun perpustakaan sekolah, yaitu: "Peningkatan minat baca dapat dilakukan dengan berbagai cara, misalnya: 1 . Menyediakan bahan bacaan; 2. Pemilihan bahan yang baik; 3. Memiliki kesadaran dan minat yang tinggi terhadap membaca; 4. Penyediaan waktu untuk membaca. Sehingga bisa kita simpulkan bahwa cara yang paling efektif untuk meningkatkan minat baca adalah menciptakan kondisi cinta baca". (Masengi et al., 2014).

\section{SIMPULAN}

Hasil yang diperoleh menunjukkan bahwa siswa menjadi memiliki sikap yang lebih baik terhadap perpustakaan sekolah, baik dari: aspek kognitif meliputi: pengetahuan, kepercayaan dan penilaian; aspek afektif; maupun konatif. Oleh karena itu diharapkan sekolah melalui guru kelas dapat secara intensif menyebarkan informasi mengenai fungsi perpustakaan sekolah, serta meningkatkan fasilitas dan pelayanan perpustakaan kepada siswa-siswinya, agar mereka terbiasa menggunakan perpustakaan sebagai langkah awal dalam membentuk generasi cinta literasi.

Gerakan cinta literasi dengan memanfaat perpustakaan sekolah membutuhkan koordinasi dari berbagai pihak, baik sekolah, termasuk guru, petugas perpustakaan, maupun teman sekolah. Pihak lainnya adalah keluarga, terutama orangtua melalui pembiasaan membaca, serta peer group yaitu teman 
sebaya di lingkungan rumah yang dapat saling mempengaruhi melalui kegiatan membaca sebuah buku secara bersamasama.

\section{DAFTAR PUSTAKA}

Agustina, S. (2014). Perpustakaan sebagai wahana terapi yang ramah disabilitas. Jurnal Edulib, 1(2), 122-146.

Aini, P. (2011). Penggunaan perpustakaan dalam meningkatkan minat baca siswa. (Skripsi). UIN Syarif Hidayatullah, Jakarta.

Alfiyani, N., Mardiati, Y., \& Khutobah. (2015). Pengembangan media pembelajaran dalam bentuk komik pada mata pelajaran IPS sub pokok bahasan detik-detik proklamasi kemerdekaan republik Indonesia untuk kelas V SD. Artikel Ilmiah Mahasiswa Universitas Jember, 1(1), 1-5.

American Library Association. (1989). Presidential committee on information literacy. Retrieved April 4, 2018, from http:/ / www.ala.org/acrl/ publications/ whitepapers/presidential\%3E

Antasari, I. W. (2016). Dukungan orang tua dalam membangun literasi anak. Jurnal Edulib, 6(2), 138-146.

Aryanti, N. Y. (2014). Pengembangan identitas melalui pertemanan antar budaya di sekolah. Jurnal Kajian Komunikasi, 2(1), 93-104.

Darmayanti, R. (2016). Membangun budaya literasi informasi bagi masyarakat kampus. IQRA': Jurnal Perpustakaan Dan Informasi, 10(1), 92101.

Diniarti, A., Rohanda, \& Sinaga, D. (2013). Analisis pengembangan perpustakaan berdasarkan SNI 7330: 2009 PPT sebagai kualitas perpustakaan. Jurnal Kajian Informasi $\mathcal{E}$ Perpustakaan, 1(1), 35-50.

Fakhrudin, M. (2003). Cara mendongeng, (disajikan pada pelatihan teknik mendongeng bagi guru taman kanakkanak se-Kabupaten Purworejo 16
Desember

2003.

(www.umpwr.ac.id/download/artik el/Cara\%20Mendongeng.pdf), 1-18.

Fauji, D. A. S., \& Ernestivita, G. (2015). Analisis karakteristik pelaku UMKM (Usaha Mikro Kecil Menengah) di kota Kediri. In Prosiding Pendidikan Karakter dalam Pembelajaran Bisnis dan Manajemen (pp. 19-20). Seminar Nasional dan Call Papers Universitas Negeri Malang.

Gemiharto, I. (2015). Teknologi 4G-Lte dan tantangan. Jurnal Kajian Komunikasi, 3(2), 212-220.

Gewati, M. (2016, August 29). Minat baca Indonesia ada di urutan ke-60 dunia. Kompas. Retrieved from https://edukasi.kompas.com/read/2 016/08/29/07175131/minat.baca.ind onesia.ada.di.urutan.ke-60.dunia

Hafiar, H., \& Sani, A. (2015). Pembentukan sikap wirausaha remaja melalui komunikasi keluarga dan pelatihan keterampilan. Jurnal Actadiurna, 11(1), 49-66.

Hestianingsih. (2012, May 15). Masuk SD harus bisa baca, tulis \& hitung, patut was-was!. Detik.com. Retrieved from https://wolipop.detik.com/read/201 2/05/15/161525/1917674/857/masu k-sd-harus-bisa-baca-tulis--hitungpatut-was-was

Khadijah, U. L. S., Rejeki, D. S., Anwar, R. K. dan Sukaesih. (2016). Literasi informasi dalam menumbuhkan motivasi berwirausaha bagi para ibu rumah tangga di kelurahan Nagasari kabupaten Karawang Barat. Jurnal Kajian Informasi $\mathcal{E}$ Perpustakaan, 4(2), 149-160.

Komariah, K., Perbawasari, S., Nugraha, A. R., \& Budiana, H. R. (2013). Pola komunikasi kesehatan dalam pelayanan dan pemberian informasi mengenai penyakit TBC pada puskesmas di kabupaten Bogor. Jurnal Kajian Komunikasi, 1(2), 173-185.

Maharani, E. (2015, December 2). Orang Indonesia lebih suka mendengar dan ngobrol daripada membaca. Republika.co.id. Retrieved from 
http://www.republika.co.id/berita/ pendidikan/eduaction/15/12/02/ny qn2d335-orang-indonesia-lebih-sukamendengar-dan-ngobrol-daripadamembaca

Masengi, A., Tabaga, A., \& Walandouw, A. (2014). Peranan orang tua dalam mengembangkan minat baca siswa SDN 121 kecamatan Malalayang Manado. Acta Diurna, 3(4), 1-6.

Muliasari, F., \& Suhardini, D. (2016). Peran fiksi remaja terjemahan dalam pencapaian perkembangan remaja di Pitimoss Fun Library. Edulib, 6(2), 189-209.

Notoadmodjo, N. (2011). Kesehatan masyarakat, ilmu $\mathcal{E}$ seni. Jakarta: Rineka Cipta.

Puspita, F. (2015). Pembentukan karakter berbasis pembiasaan dan keteladanan. (Tesis). UIN Sunan Kalijaga, Yogyakarta.

Rodin, R. (2015). Urgensi kualitas pelayanan perpustakaan perguruan tinggi. Jurnal Kajian Informasi $\mathcal{E}$ Perpustakaan, 3(1), 101-110.

Senova, A. (2014). Literasi media sebagai strategi komunikasi tim sukses relawan pemenangan pemilihan presiden Jokowi JK di Bandung. Jurnal Kajian Komunikasi, 4(2), 142-153.

Setianti, Y., \& Hafiar, H. (2009). Tanggapan siswa Madrasah Tsanawiyah Miftahul Ulum terhadap kesehatan reproduksi remaja. (Laporan penelitian). Universitas Padjadjaran, Sumedang.

Setianti, Y., Hafiar, H., \& Nugraha, A. R. (2009). Pelatihan penulisan untuk majalah dinding bagi siswa Madrasah Tsanawiyah Mathlaul Ulum desa Tanjung Kamuning kecamatan Tarogong
Garut. (Laporan penelitian). Universitas Padjadjaran, Sumedang.

Setyaningsih, E. T. (2012). Hubungan faktor enabling dengan pemakaian alat pelindung diri (apd) pada tenaga kerja di PT Suwastama Pabelan. (Skripsi). Universitas Sebelas Maret, Surakarta.

Simanjorang, F. O. M. (2013). Efektivitas program pelatihan keterampilan bagi penyandang cacat tuna rungu wicara di UPT pelayanan sosial tuna rungu wicara dan lansia Pematang Siantar. Welfare State, 2(4), 1-16.

Sugara, S., Rusmono, D., \& Agustina, S. (2016). Alive library sebagai brand positioning di Perpustakaan Sekolah Bina Persada. Jurnal Edulib, 6(1), 82104.

Surachman, A. (2013). Manajemen perpustakaan sekolah. Makalah Disampaikan Dalam BIMTEK Direktorat Jenderal Budidaya Perikanan, Kementerian Perikanan Dan Kelautan RI, 1-10.

Tarigan, G. H. (2008). Membaca: sebagai suatu keterampilan berbahasa. Bandung: Angkasa.

Triatma, I. N. (2016). Minat baca pada siswa kelas VI Sekolah Dasar Negeri Delegan. E-Jurnal Prodi Teknologi Pendidikan, 5(6), 166-178.

Zulhaqi, R. (2013, October 14). Ingat efeknya.. biarkan anak tumbuh sesuai usianya!. Kompas. Retrieved from https:/ / edukasi.kompas.com/read/2 013/10/14/1618542/Ingat.Efeknya.Bi arkan.Anak.Tumbuh.Sesuai.Usianya.

Zulnuraini. (2012). Pendidikan karakter: konsep, implementasi dan pengembangannya di sekolah dasar di kota Palu. Jurnal DIKDAS, 1(1), 111. 
